\title{
POSSIBILITIES OF USING EARTH OBSERVATIONS FOR ANALYZING THE ENVIRONMENTAL IMPACTS OF FORMER COAL MINE IN VIHOVICI
}

\author{
Ivana Mikulić \\ KTM Brina d.o.o. Posušje, mag.ing.aedif. \\ Corresponding author: ivana.mikulic91@gmail.com \\ Marinela Nuić \\ mag.ing.aedif.
}

\begin{abstract}
The paper presents recently developed methods along with a toolset for monitoring the environmental impact of mining operations, and in particular, for analyzing water quality, by using earth observations. Cuttingedge technology is proposed for the combined use of aerial lightweight measurements, including hyperspectral imaging spectroscopy and unmanned aerial vehicles (UAVs). Water quality was analyzed using airborne and in situ measured water data. Measurements of the water-leaving radiance $(\mathrm{Rw})$ spectra provide sufficient information to estimate water quality because of the combination of parameters derived from the measurements: total suspended matter (TSM), phytoplankton (with the most active component Chlorophyll a, CHL-a) and colored dissolved organic matter (CDOM). The in situ Rw spectra were used along with the in situ concentrations measurements to find the most optimal band ratio algorithm for each water quality parameter. Analysis of the linear regression between the band ratios and the concentration measurements showed very strong correlation. The small root mean square errors (RMSE) for the most of the parameters lead to conclusion that there is no significant change in water quality resulting from a latent effect of the old mining industry or waste dumping within the region of Mostar.
\end{abstract}

Keywords: aerial lightweight measurements; hyperspectral imaging spectroscopy; unmanned aerial vehicles (UAVs); water quality

\section{MOGUĆNOSTI KORIŠTENJA DALJINSKIH ISTRAŽIVANJA ZA ANALIZU UTJECAJA NA OKOLIŠ BIVŠEG RUDNIKA VIHOVICI}

Sažetak: U radu su prikazane nedavno razvijene metode i skup alata za praćenje utjecaja na okoliš rudarskih aktivnosti, posebice za analizu kakvoće vode pomoću daljinskih istraživanja. Prikazane su moderne tehnologije koje kombiniraju vizualizacijske senzore, uključujući hiperspektralnu spektroskopiju, i bespilotne letjelice (UAV). Kakvoća vode analizirana je pomoću daljinskih i in situ mjerenja. Mjerenja spektra reflektiranog zračenja s vodene površine (Rw) osiguravaju dovoljno informacija za procjenu kakvoće vode zbog kombinacije parametara proizašlih iz mjerenja: ukupne suspendirane tvari (TSM), fitoplanktona (gdje je najaktivnija komponenta Chlorophyll a, CHLa) i otopljene obojane organske tvari (CDOM). In situ RW spektar je korišten paralelno $s$ in situ mjerenjima koncentracija kako bi se definirao optimalni algoritam spektralnog područja za svaki parametar kakvoće vode. Analiza linearne regresije između spektralnog područja i mjerenja koncentracije pokazala je jaku korelaciju. Mala vrijednost srednje kvadratne pogreške (RMSE) za većinu parametara dovodi do zaključka kako ne postoji značajna razlika u kakvoći vode zbog latentnog utjecaja nekadašnje rudarske industrije ili odlaganja otpada u okolici Mostara

Ključne riječi: vizualizacijski senzori; hiperspektralna spektroskopija; bespilotna letjelica (UAV); kakvoća vode 


\section{INTRODUCTION}

The main purpose of this work is to demonstrate the possibility of using remote sensing data to evaluate environmental impacts of the coal mine in Vihovici, which is being used as a waste dump, and the effects of the mine on water quality in the Neretva River. Several previous studies were conducted on the Vihovici coal mine to evaluate its environmental impact. One of the first studies "Water Quality Management" was conducted by the Adriatic Sea Watershed Agency, Mostar; in this study, continuous measurements of water quality parameters (general chemical parameters, dissolved nutrients, and metals) were carried during the period 2005-2007 in the Neretva River and at several other locations. Some other studies (Borehole geophysical data for geothermal anomalies from burning coal seams (temperature, resistivity) 2006; Study for the rehabilitation of the mine site by Fichtner/dplan/HarbourDom, financed by KfW Bankengruppe and the City of Mostar: Preparatory Stage Report (Fichtner et al., 2006) and Feasibility Report (Fichtner et al., 2007); Final report on extinction and rehabilitation works of the former Vihovici coal mine (KfW Bankengruppe, 2009) [1]...), have shown that the danger to the environment in the Vihovici complex and its surroundings are substantially less than originally assumed.

In addition to these studies, many researches have shown the potential of remote sensing monitoring environmental impact. In [2], the remote sensing techniques that can be used to monitor water quality parameters (i.e., suspended sediments (turbidity), chlorophyll, and temperature) with the integrated use of remotely sensed data, GPS, and GIS are described. As stated in [3], the miniaturization of sensors makes it possible to capture color images from unmanned aerial systems (UAS) with a very high spatial resolution. UAS can be deployed in a very flexible manner, allowing high temporal resolution imaging. In [4], an unmanned aerial vehicle (UAV) was used to make highly accurate and efficient measurements of methane, carbon dioxide, and water vapor concentrations at low-altitudes and in remote or dangerous locations. The review in [5] provides a comprehensive overview on the ways in which remote sensing can support lake research and monitoring; this review focuses on the remote sensing indicators of lake properties, such as water transparency, biota, bathymetry, water temperature, and ice phenology.

The results and data used in this study were obtained from FP7 ImpactMin project in which a team of experts from the Faculty of Civil Engineering University of Mostar participated.

\section{GENERAL INFORMATION ABOUT SITE AND ENVIRONMENTAL IMPACTS}

Vihovici is a former coal mine located on the northern periphery of Mostar Valley in Bosnia and Herzegovina. The mine was opened in 1881, and it is estimated that during the period between 1919 and 1991, 11 million tons of brown coal were extracted [6]. The mine is located in a karst landscape, with typical associated structures (e.g., caverns, sinkholes, and dolines). The problems caused by the former mine increased when it was transformed into an unregulated municipal waste dump, and when the underground coal (and organic material) fires ignited, spewing hazardous gas in the middle of an urban area. The city of Mostar, with approximately 100,000 inhabitants, is located adjacent to the Vihovici Lake (Figures 1 and 2). The former coal mining activities had a substantial impact on the topography of the site in terms of the numerous tailings from the underground phase, overburdened scrap heaps deposited during the open-pit coal mining, and the open pit, which is now occupied by a pit-lake, created by the surface mining operations that continued until 1991.

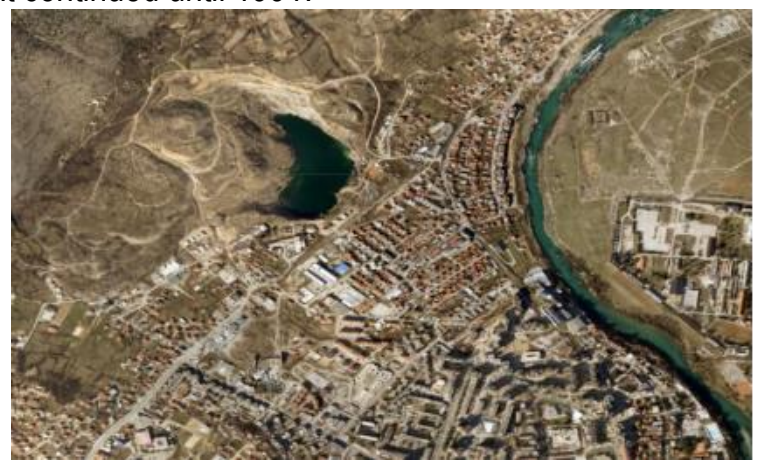

Figure 1 Orthophoto of the demonstration site (2004) (with Vihovici Lake to the left and the Neretva River to the right) [7] 


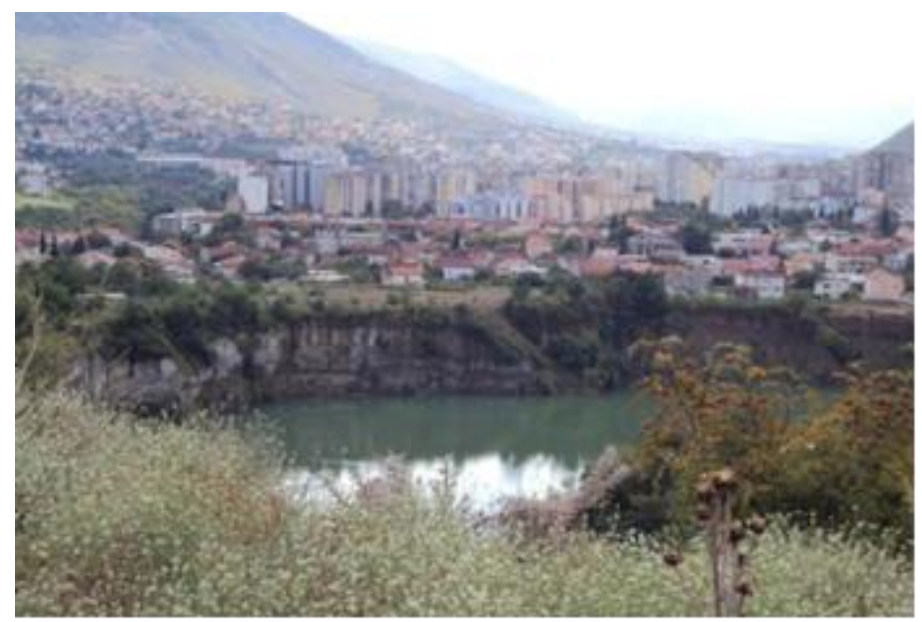

Figure 2 Position of the Vihovici Lake relative to Mostar urban area [7]

The affected area extends across 76 ha, with surface operations being carried out over 43.2 ha and an open pit of area $7 \mathrm{ha}$. The site has a great influence on the urban area owing to the fact that the distance from the mine to the city center of Mostar is only about $500 \mathrm{~m}$ and that to the Neretva River, which is one of the longest and hydrologically richest rivers in Bosnia and Herzegovina, is only about $450 \mathrm{~m} \mathrm{[7].}$

In this research, airborne hyperspectral data, ground-based spectral data, and water-quality measurements for the Vihovici coal mine were coupled with the high-resolution UAV imaging conducted in Mostar during May and June 2011 over the mine. Hyperspectral imagery was used to observe waste ponds in order to investigate potential sources of water, air, and soil pollution.

\section{METHODOLOGY OF REMOTE SENSING RESEARCH}

SmartPlanes UAV (Unmanned Aerial Vehicle) is a small unmanned aircraft equipped with a photo camera for obtaining highly detailed orthophotos and digital elevation models (DEM). The plane can be easily transported in a small suitcase and can be made ready for operation within minutes with a minimal footprint. It is hand-launched and landed, and it can take off from and land on almost on any surface [7]. Imaging spectrometry data or hyperspectral imagery $(\mathrm{HSI})$ acquired using airborne systems have been used by the geological community since the early 1980s, and they represent a mature technology. The spectral range 0.4-2.5 $\mu \mathrm{m}$ provides abundant information about many important minerals on the earth's surface. Imaging spectrometers or hyperspectral sensors provide a unique combination of both spatially contiguous spectra and spectrally contiguous images of the earth's surface unavailable from other sources [8]. Hyperspectral remote sensing images used in this particular research were acquired using the AISA Eagle hyperspectral sensor; the main characteristics of this sensor are presented in Table $1[7]$.

Table 1 Equipment and acquisition parameters [7]

\begin{tabular}{ccccccccc}
\hline Aircraft & $\begin{array}{c}\text { GPS/INS } \\
\text { system }\end{array}$ & Sensor & $\begin{array}{c}\text { No. of } \\
\text { bands }\end{array}$ & $\begin{array}{c}\text { Spectral } \\
\text { range } \\
(\mathbf{n m})\end{array}$ & $\begin{array}{c}\text { Bandwidth } \\
(\mathrm{nm})\end{array}$ & $\begin{array}{c}\text { Spatial } \\
\text { resolution }\end{array}$ & Swath/AGL & Overlap \\
\hline $\begin{array}{c}\text { Piper PA } \\
23-250 \\
\text { Aztec }\end{array}$ & $\begin{array}{c}\text { OXTS 3003, } \\
\text { with } \\
\text { Omnistar }\end{array}$ & $\begin{array}{c}\text { AISA } \\
\text { Eagle II }\end{array}$ & 253 & $400-975$ & 2.5 & 1.1 & $\begin{array}{c}1126 / 1655 \\
\mathrm{~m}\end{array}$ & $20 \%$ \\
\hline
\end{tabular}

The entire Vihovici mine complex along with the important river section of Neretva was imaged in order to include most of the water sampling sites. Five flights were carried out with SmartPlanes UAV to collect highresolution $(5 \mathrm{~cm})$ aerial photographs of the open pit area and the sampling sites in the Neretva River. The stereo imagery of the open pit area was used to generate a digital surface model with a vertical precision greater than 10 $\mathrm{cm}$. Figure 3 shows the difference in spatial detail between a hyperspectral natural color composite (1-m resolution) and digital orthophoto acquired by UAV imaging (5-cm resolution) [7]. 


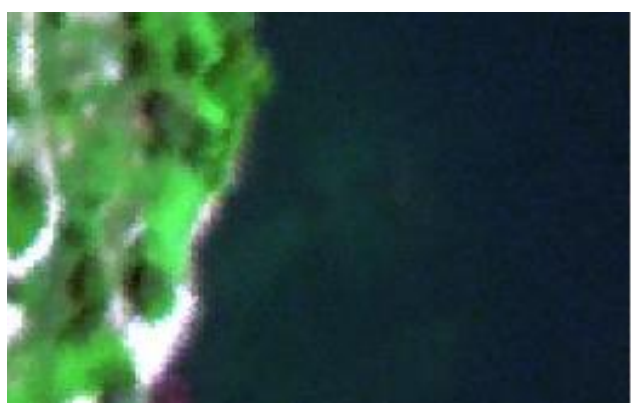

a)

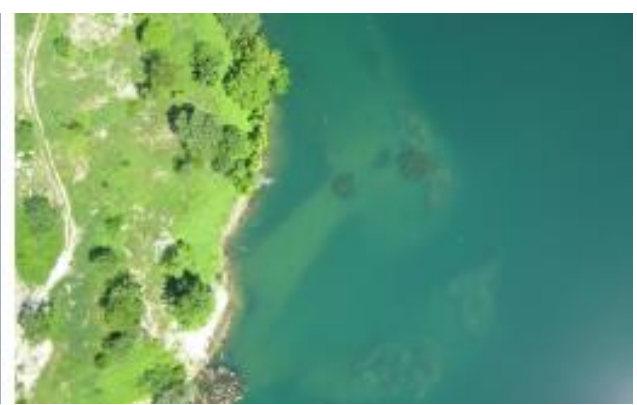

b)

Figure 3 Comparison of (a) hyperspectral natural color composite (1-m resolution) and (b) digital orthophoto acquired by UAV imaging (5-cm resolution) [7]

The SmartPlane flight paths covered three areas in the Mostar Valley (as showed in Figure 4) in order to support the interpretation of the field measurements, the hyperspectral imagery, and ground-based surveys. UAV overflight was undertaken to acquire high-resolution images of the Vihovici mine and Neretva River and to assist in the interpretation of targets with added spatial detail. The very-high-resolution imagery is an excellent tool to understand the acquired spectral and analytical data better [7].
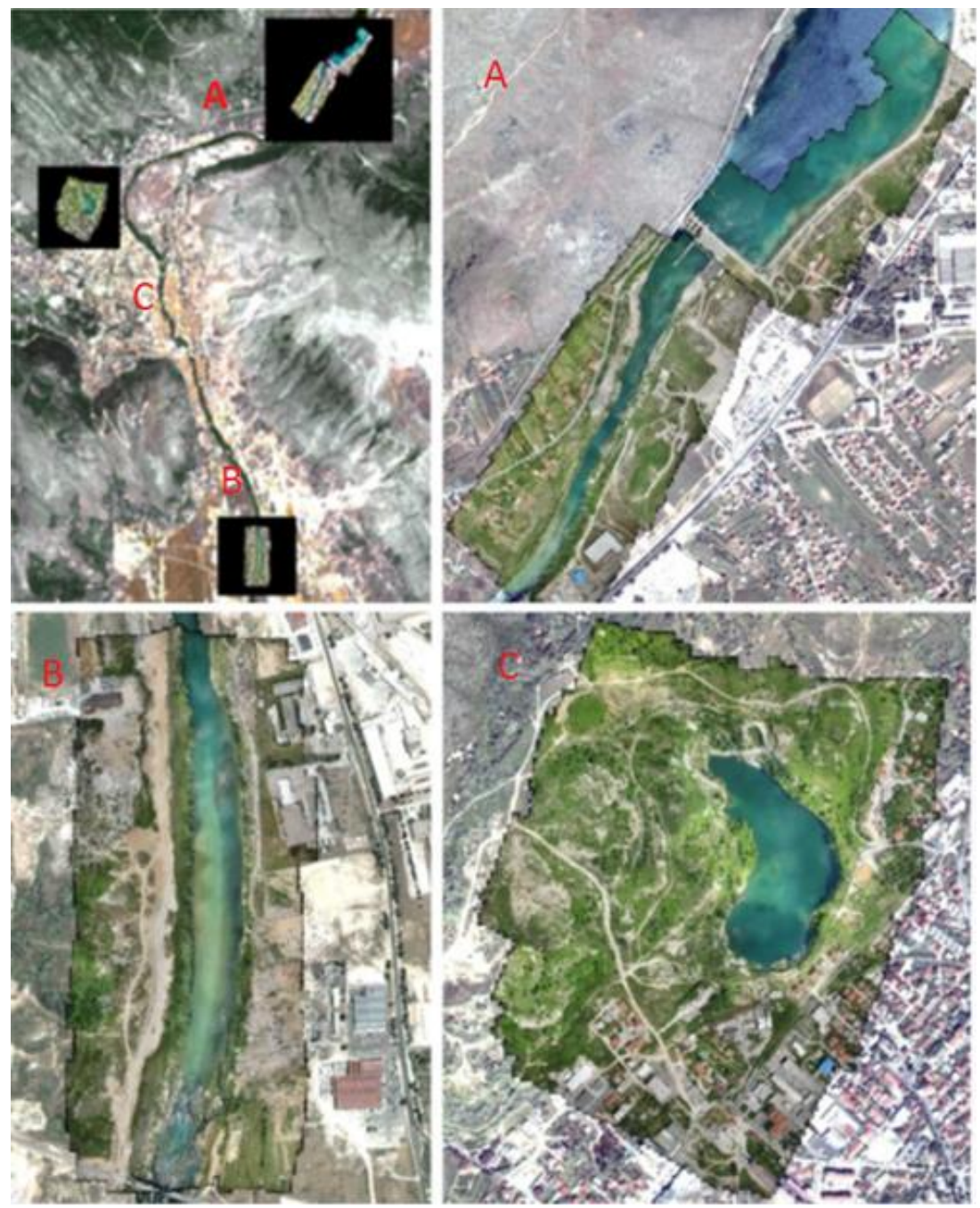

Figure 4 Overview of the study areas along the flight path; the SmartPlane images are overlain on an ASTER image (top-left), and individual areas (A, B, and C) are overlain on WorldView-2 images [7] 
The main challenges in airborne study of the Mostar site are the low-altitude required for airborne operations and data acquisition over a heavily urbanized area. Operating in a congested area, with overhead infrastructure (e.g., power-lines) in a relatively narrow mountainous valley, requires careful mission planning and safety considerations to minimize any potential risk on the ground [9].

\section{WATER QUALITY ANALYSIS}

The airborne AISA-EAGLE data were corrected for geometric and atmospheric distortions. The applied combination of FLAASH and empirical line methods for atmospheric correction worked fine for land applications. However, a vicarious calibration was necessary to extract the water reflectance from the AISA hyperspectral imagery because water appears much darker than the land targets owing to the lower radiance values of the water. The empirical line method converts at-sensor radiance values to surface reflectance values, but the result may lead to the overestimation of the water reflectance values. Furthermore, sunlight directly reflected at the air-water interphase (i.e., skylight reflection) greatly influences the lower wavelength part of the spectrum, resulting in higher water reflectance values (Figure 5) [7].

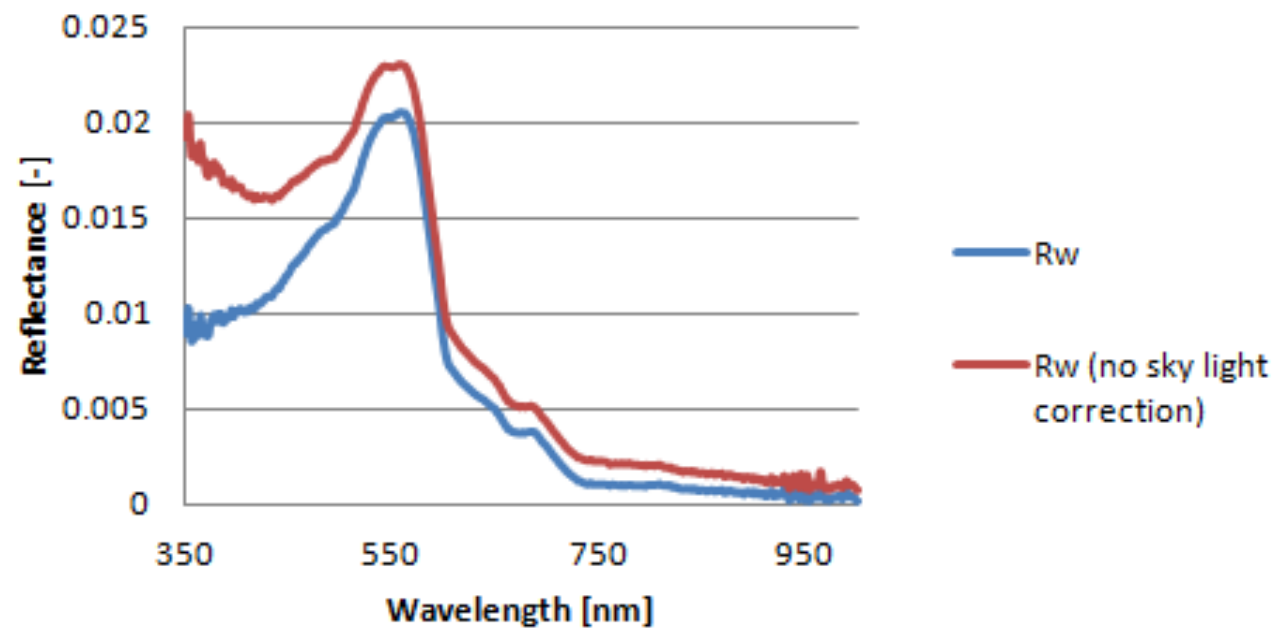

Figure 5 Water reflectance to skylight effect [7]

Figure 6 shows the spatial distribution of remotely sensed water quality parameters (ortho Phosphor (mg/l), cadmium $(\mu \mathrm{g} / \mathrm{l})$, lead $(\mu \mathrm{g} / \mathrm{l})$, and iron $(\mu \mathrm{g} / \mathrm{l})$ ) in the lake as well as the Neretva River, along with the relationship between the in situ measurements of the parameters and the parameters derived from the airborne (hyperspectral) imagery.

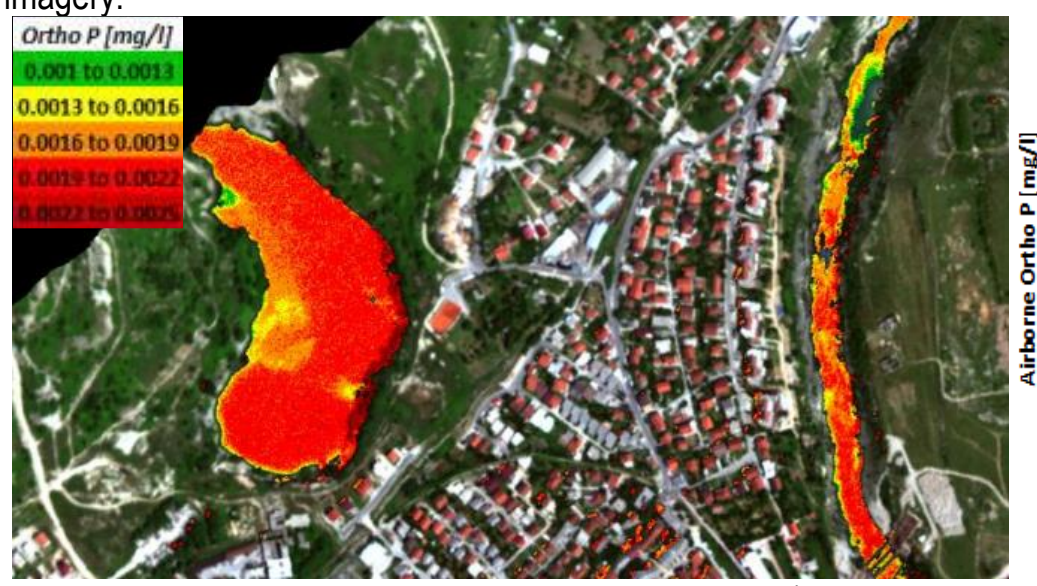

a)

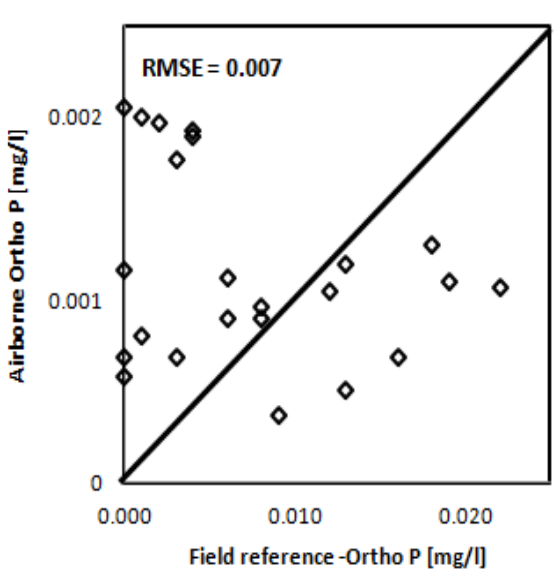

Field reference -Ortho $P[\mathrm{mg} / \mathrm{l}]$ 


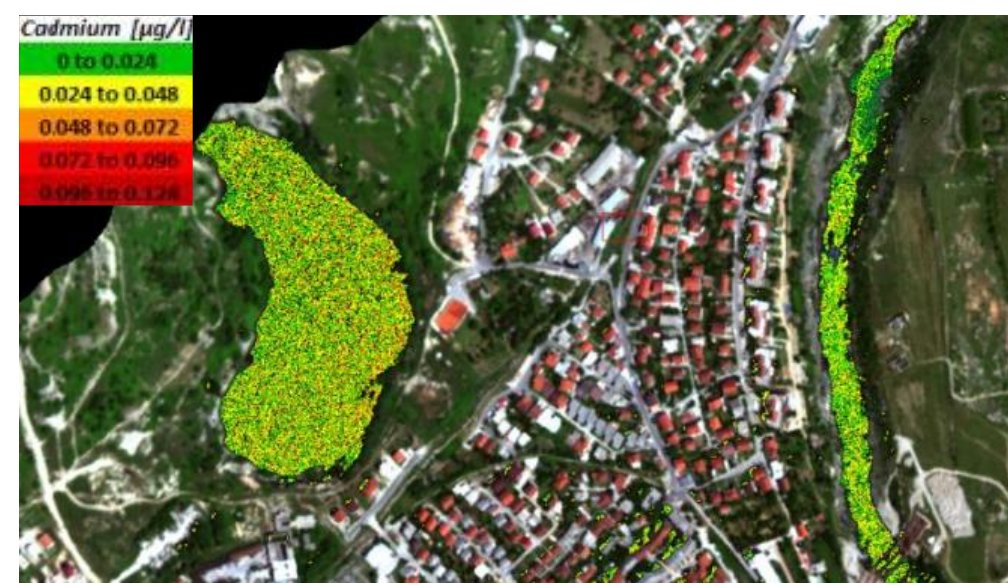

b)

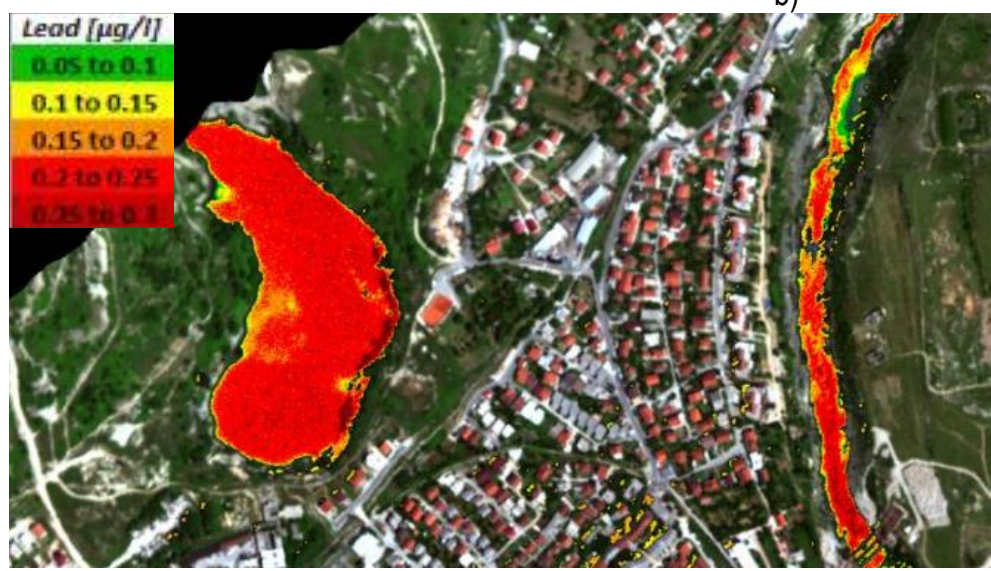

c)

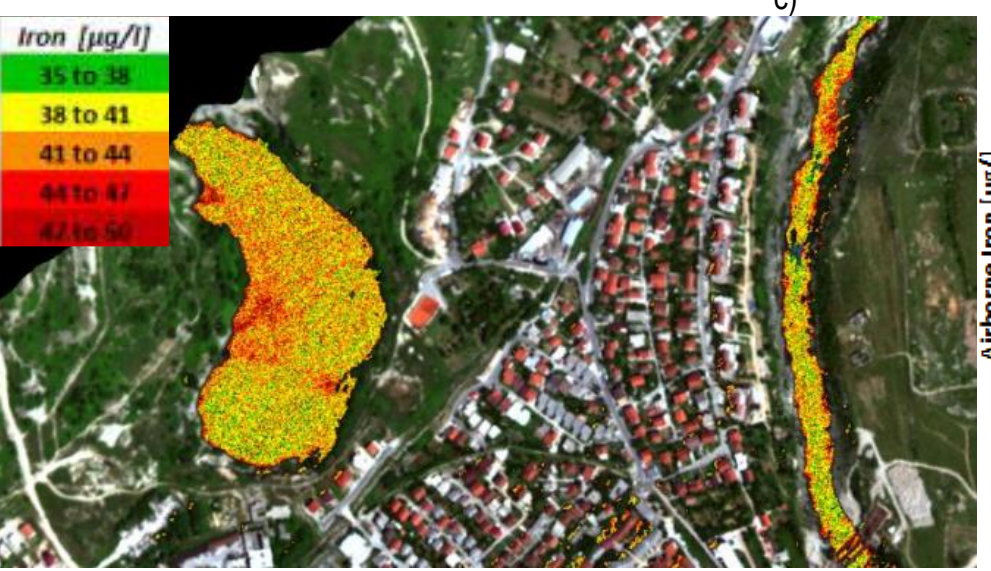

d)
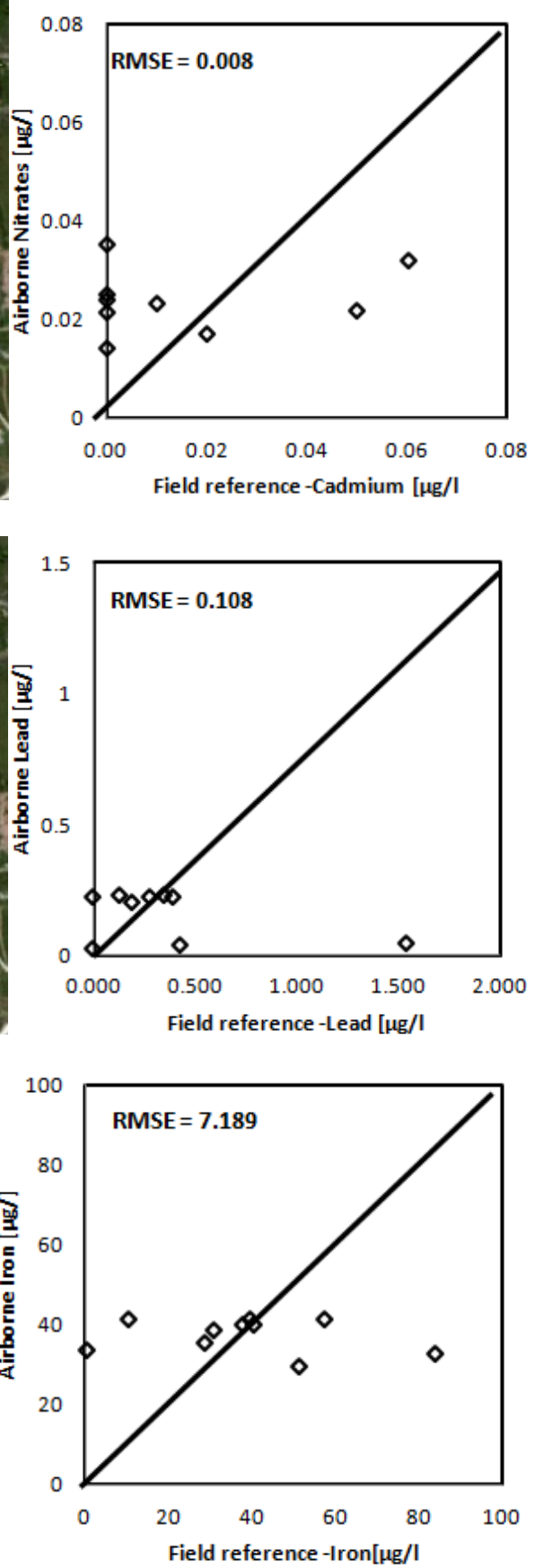

Figure 6 Mostar water quality map and ground validation results: (a) ortho phosphor, (b) cadmium, (c) lead, and (d) iron [7]

As shown in Figure 6, good results were obtained with the remote sensing techniques with relatively low root mean square errors (RMSE) values and narrow concentration ranges.

The study area was divided into two parts: Vihovici Lake (Fig. 7a) and the Neretva River (Fig.7b). The airborne imagery for the relevant areas was merged together. Finally, a water mask was created based on the near infrared (NIR) band values: NIR radiation is well absorbed by water resulting in very low radiance values in the NIR band for water targets, and therefore, water can be easily distinguished from the land surfaces. A screenshot of the corrected image along with the spectra of two water targets (green and red dots) is shown in Figure 7 [7]. 


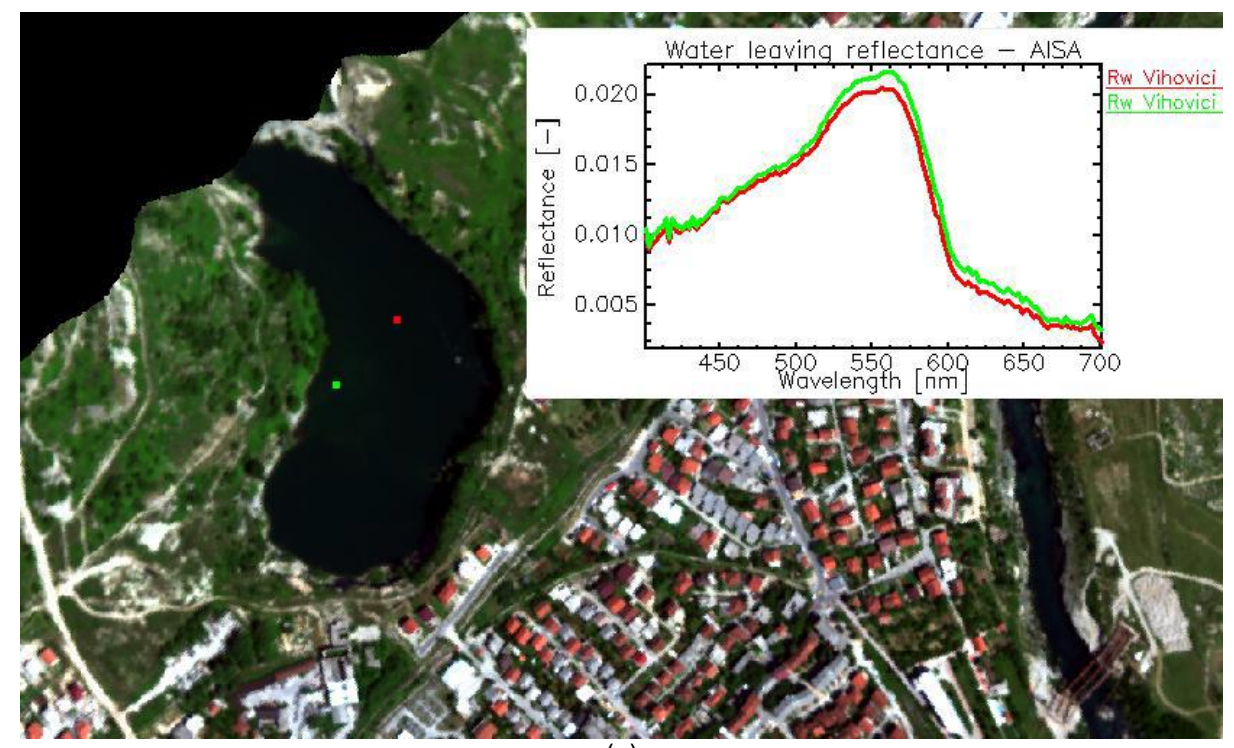

(a)
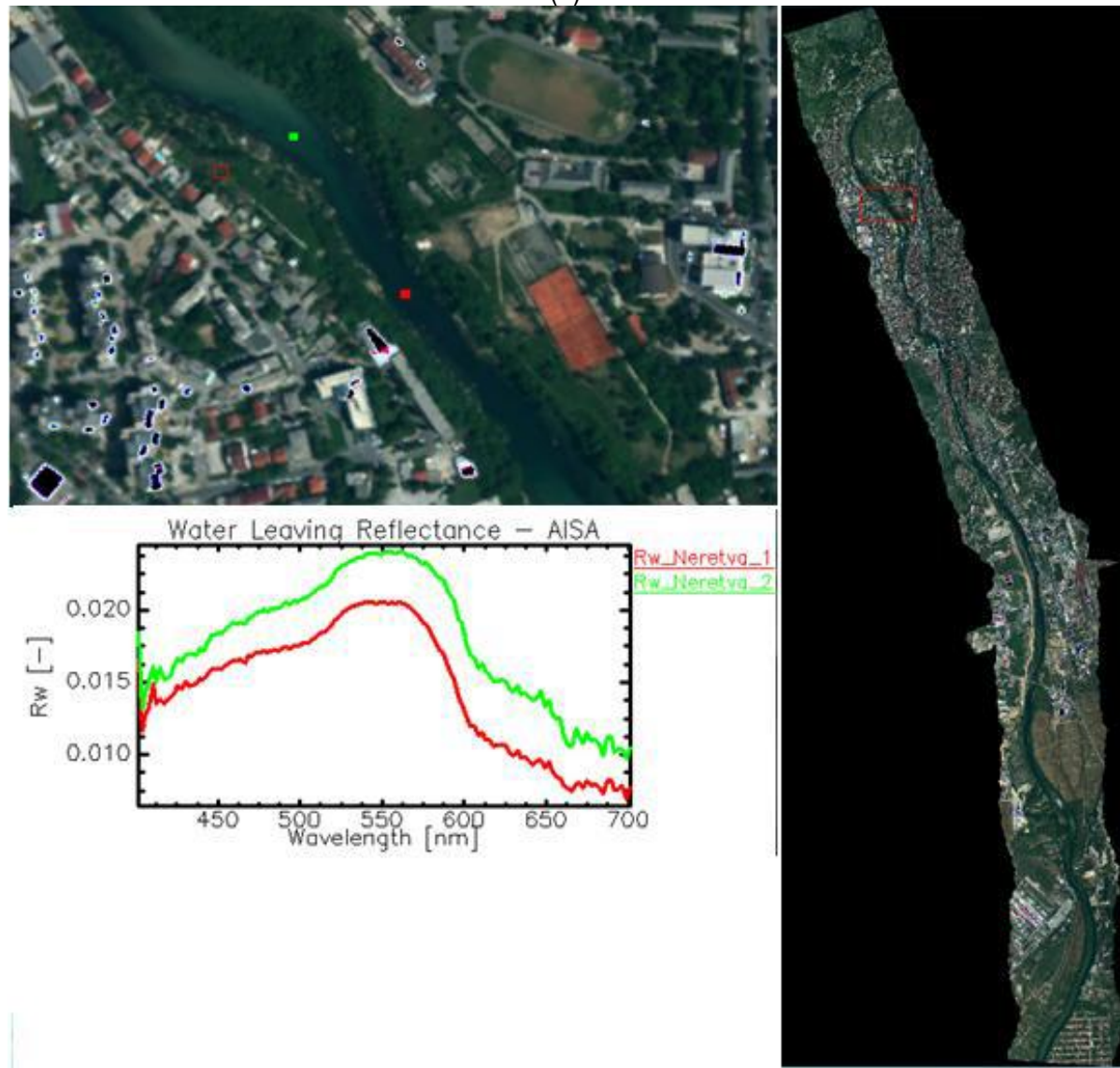

(b)

Figure 7 Water-leaving reflectance based on AISA for (a) Vihovici Lake and (b) Neretva [7]

\subsection{In situ water spectra analysis}

The Rw spectra measured using an optical system is in reality a spectral mixture of the optically active constituents in the water. These include water, total suspended matter (TSM), phytoplankton (with the most active component being $\mathrm{CHL}-\mathrm{a})$, and colored dissolved organic matter (CDOM). A combination of these parameters can give an indication of water quality. Deriving this water quality information for coastal and inland waters is more complex than deriving it for oceans because the optically active constituents have a combined impact on the water-leaving 
Possibilities of using earth observation for analysing the environmental impacts of former coal mine in Vihovici

radiance. The Rw spectra measured during the Mostar field campaign are related to the $\mathrm{CHL}$ concentration (Figure 8). For the measurement conducted in Vihovici Lake, which has low CHL concentrations, the TSM concentration has a notable influence on the spectra. A similar relationship can be found in the case of Vihovici Lake with higher Rw spectra and higher concentrations of TSM. The increase in CHL concentration (range: 0.108 to $1.879 \mu \mathrm{g} / \mathrm{l}$ ), which should lead to a decrease in Rw value at certain wavelengths (e.g., $510 \mathrm{~nm}, 555 \mathrm{~nm}$ and $670 \mathrm{~nm}$ ), was not detected. However, the measurements taken along the Neretva River were highly influenced by the river bottom reflectance. Despite the relatively constant concentration along the river, the Rw spectra changes because of the changing river bottom and adjacency effects (green spectra in measurements in the Neretva River) [7].
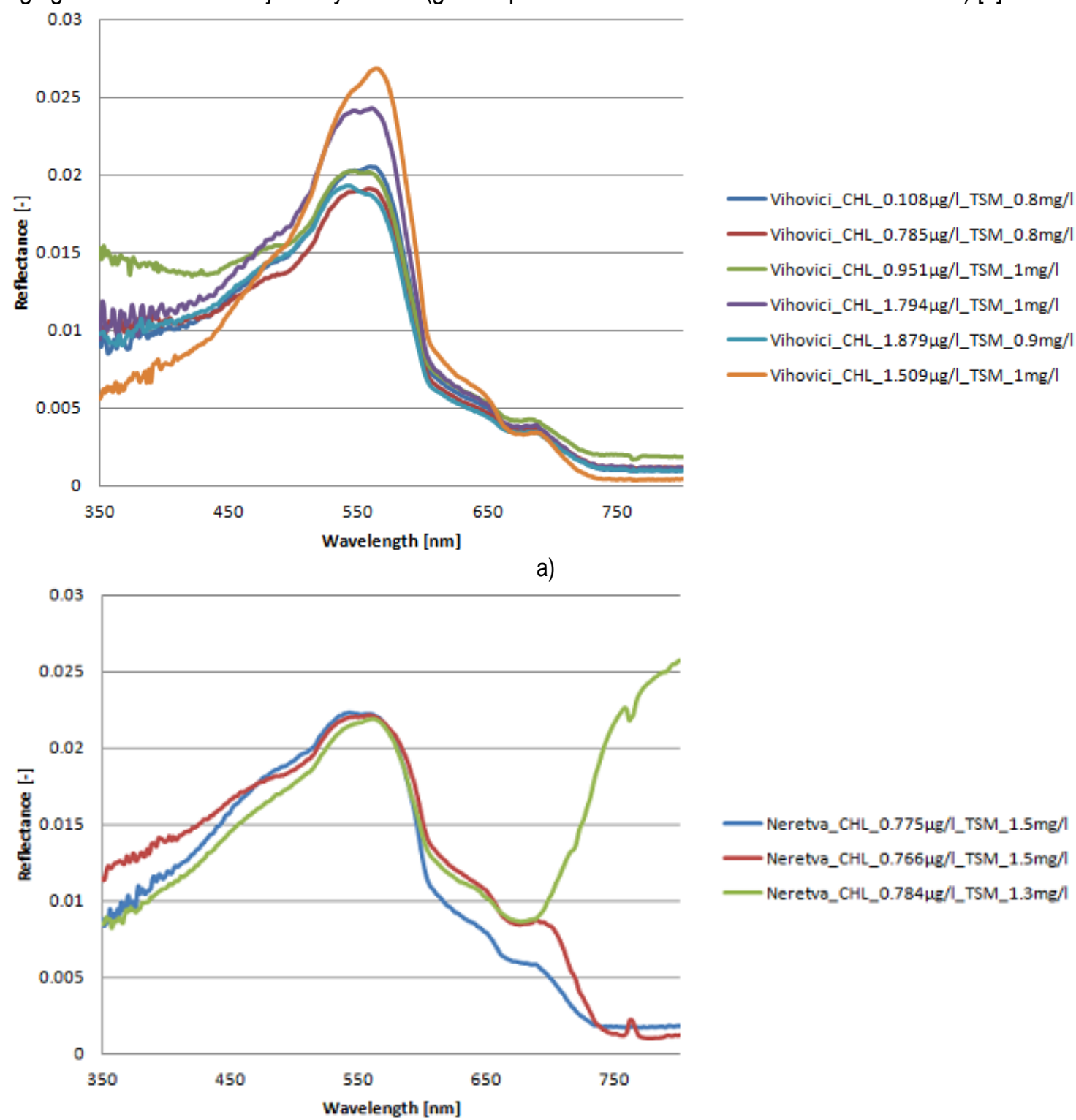

b)

Figure 8 Rw spectra measured during the Mostar field campaign along with the in situ CHL concentration values for (a) Vihovici Lake and (b) Neretva River [7]

The relationship between the Rw spectra and the different water quality parameters was further investigated by linear regression analysis. First, the in situ Rw spectra were resampled to the AISA-EAGLE spectral band configuration. Next, a normalized spectral band ratio was calculated for all possible band combinations according to the following equation:

$$
W Q P_{i}=I_{i}+S_{i} * \frac{b 1_{i}-b 2_{i}}{b 1_{i}+b 2_{i}}
$$


where WQPi represents the water quality parameter under consideration; I, the calculated intercept, which is the constant term in the regression equation (additive factor/offset); and $S$, the calculated slope. Further, $b_{1 i}$ and $b_{2 i}$ are the specific spectral band pixel values. The advantage of working with band ratios is that possible errors in the atmospheric corrections are partly eliminated. The linear regression between these band ratios and the different water quality parameters were calculated, and the resulting $R^{2}$ was visualized in a band ratio plot (Figure 9 ). Different wavelength regions that have the highest correlation with the relevant water quality parameter are shown in the figure. For TSM, the highest correlation was found for wavelengths $550 \mathrm{~nm}$ to $600 \mathrm{~nm}$, while for CHL-a, the highest correlation corresponded to $480-575 \mathrm{~nm}$ and around $675 \mathrm{~nm}$. These are highly correlated with the regions found for nitrates and total nitrogen, as these nutrients induce the growth of phytoplankton, and thus CHL-a, in the water. Phosphorus and cadmium concentrations had very poor relationship with the calculated band ratios, while lead and iron had regions with significant correlation coefficients around 425 and $550 \mathrm{~nm}$, respectively [7].

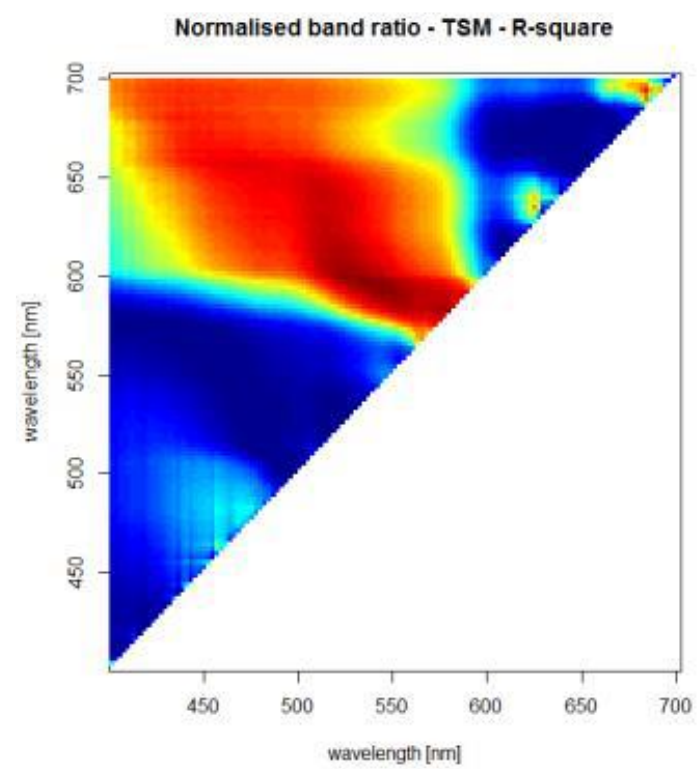

a)

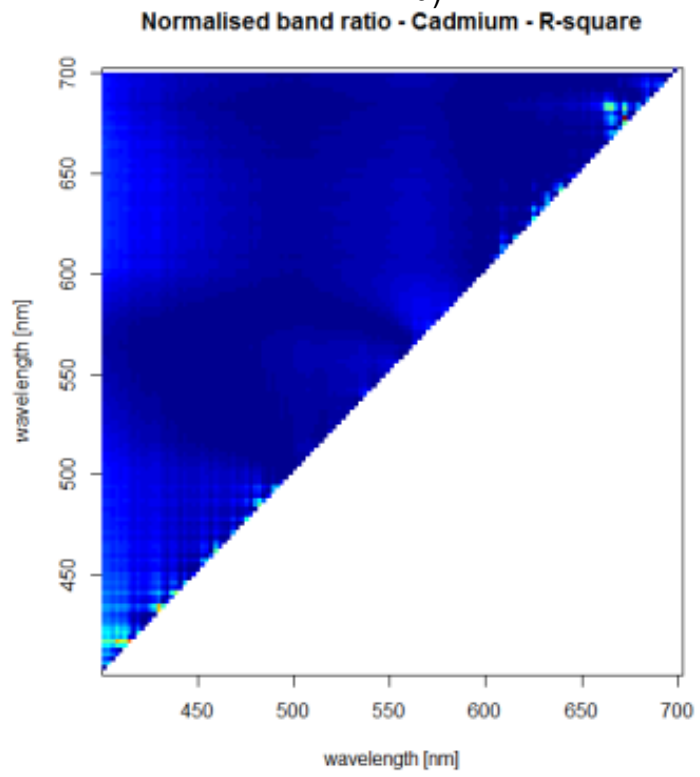

c)

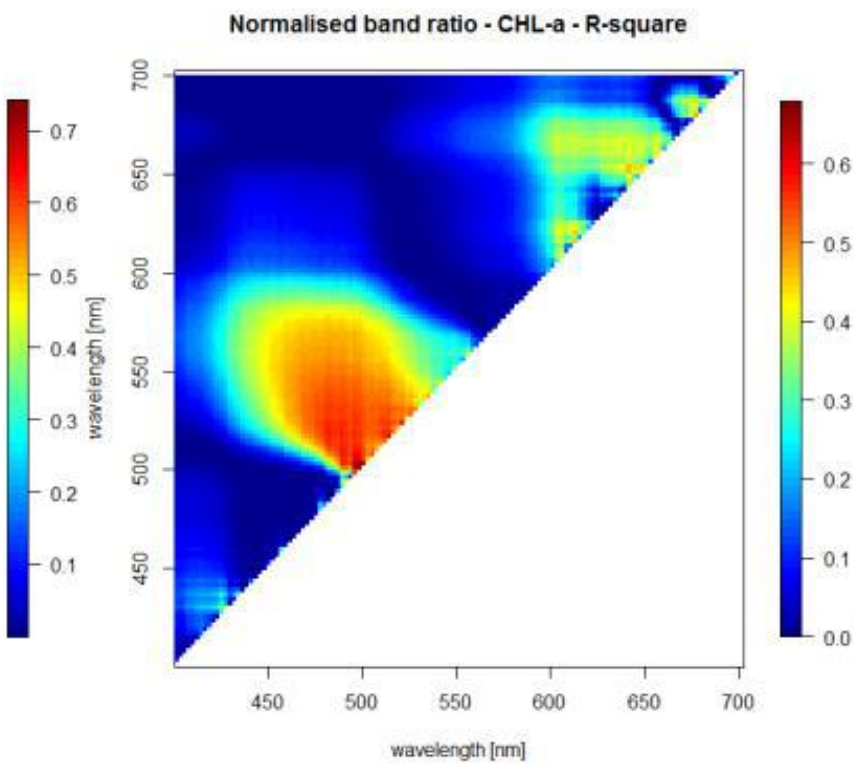

(b)

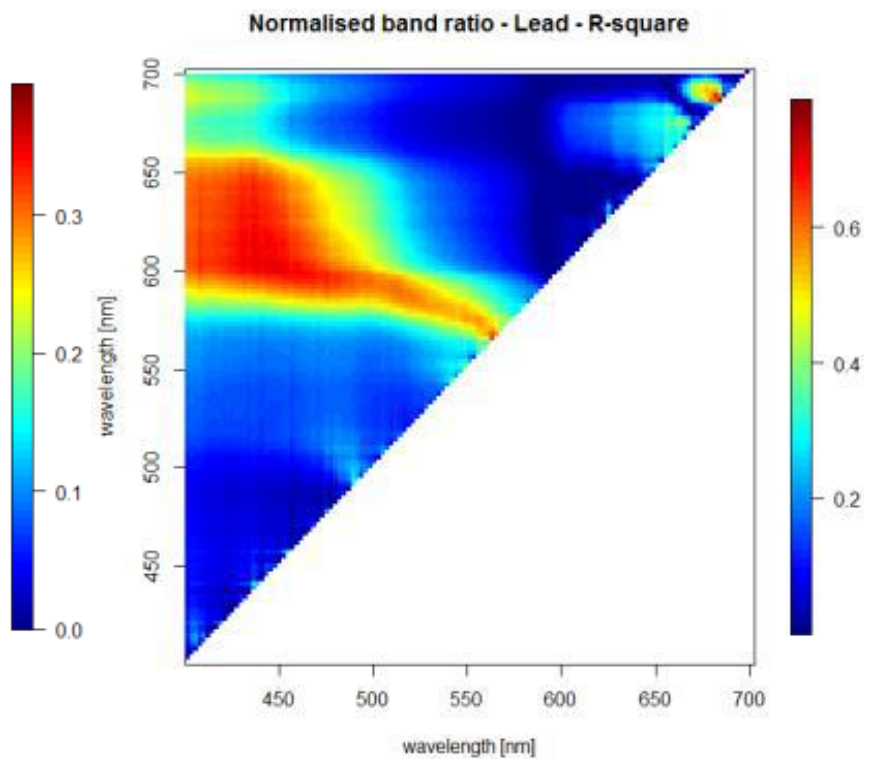

(d) 


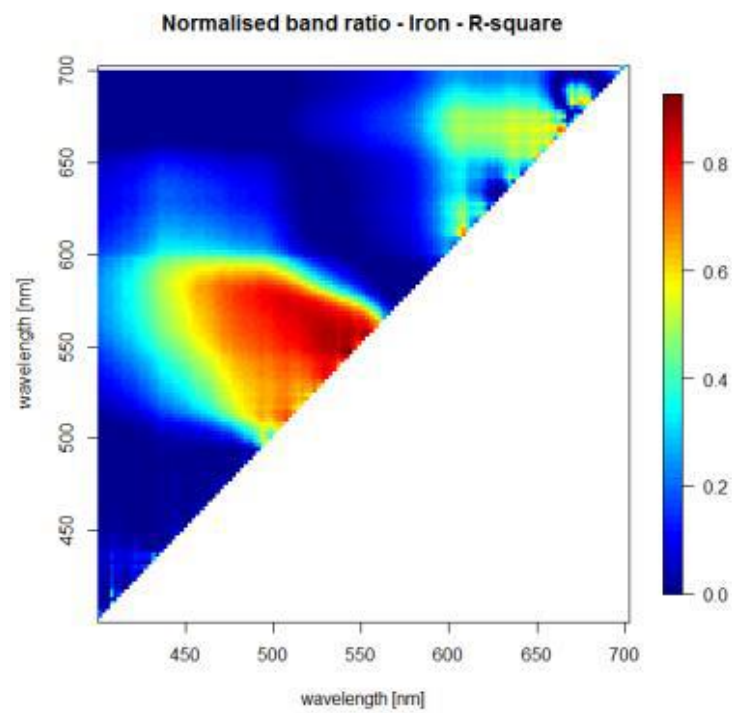

(e)

Figure 9 Band ratio significance plots: $R^{2}$ of the linear regression between the band ratio and (a) TSM, (b) $\mathrm{CHL}$, (c) cadmium, (d) lead, and (e) iron [7]

The band combinations with the highest coefficients of determination $\left(R^{2}\right)$ for each water quality parameter are listed in Table 2 along with the RMSE. In this analysis, neighboring band combinations were not considered because they are likely to be highly correlated [7].

Table 2 Results of the linear regression analysis with best ratio combination for each water quality parameter [7]

\begin{tabular}{|c|c|c|c|c|c|c|}
\hline Parameter & Band $1(\mathrm{~nm})$ & Band $2(\mathrm{~nm})$ & Intercept & Slope & RMSE & $R^{2}$ \\
\hline Chlorophyll a [ $[\mu \mathrm{g} / \mathrm{l}$ & 496.22 & 507.69 & 0.0445123 & -33.2522 & 0.487851 & 0.5963954 \\
\hline Suspended material [mg/l] & 535.21 & 596.58 & 1.989045 & -3.14795 & 0.153978 & 0.7264311 \\
\hline Nitrites [ $\mathrm{N} \mathrm{mg/l]}$ & 505.4 & 516.86 & 0.0033592 & 0.054159 & 0.000805 & 0.7396632 \\
\hline Nitrates [ $\mathrm{N} \mathrm{mg/l]}$ & 512.28 & 523.74 & 0.0781271 & -4.31354 & 0.036929 & 0.8586331 \\
\hline Total Nitrogen [N mg/l] & 507.69 & 519.16 & 0.2085437 & -3.62237 & 0.077451 & 0.5646506 \\
\hline Total Phosphorous [P mg/l] & 403.69 & 414.64 & 0.122 & 2.741283 & 0.035148 & 0.6223178 \\
\hline Ortho Phosphor [P mg/l] & 537.5 & 579.95 & -0.000254 & 0.026703 & 0.001706 & 0.3215081 \\
\hline Cadmium [Cd $\mu \mathrm{g} / \mathrm{l}]$ & 665.46 & 682.08 & 0.0187707 & -0.74738 & 0.017553 & 0.1918868 \\
\hline Lead [Pb $\mu \mathrm{g} / \mathrm{l}]$ & 443.47 & 603.7 & -0.071226 & 1.365746 & 0.091669 & 0.7059899 \\
\hline Iron $[\mathrm{Fe} \mu \mathrm{g} / \mathrm{l}]$ & 542.09 & 556.2 & 30.36372 & -1119.24 & 6.114444 & 0.8844359 \\
\hline
\end{tabular}

\subsection{Airborne in comparison with in situ research}

The airborne Rw spectra were validated with the in situ Rw spectra, as shown in Figure 10, for the two measurement locations. A $3 \times 3$ pixel-bounding box was set to calculate the average AISA Rw spectrum owing to accounting inaccuracies in the geometric correction of the airborne data. Comparison of the airborne and reference reflectance curves (Figure 10) shows high correlation between the two Rw spectra [7].

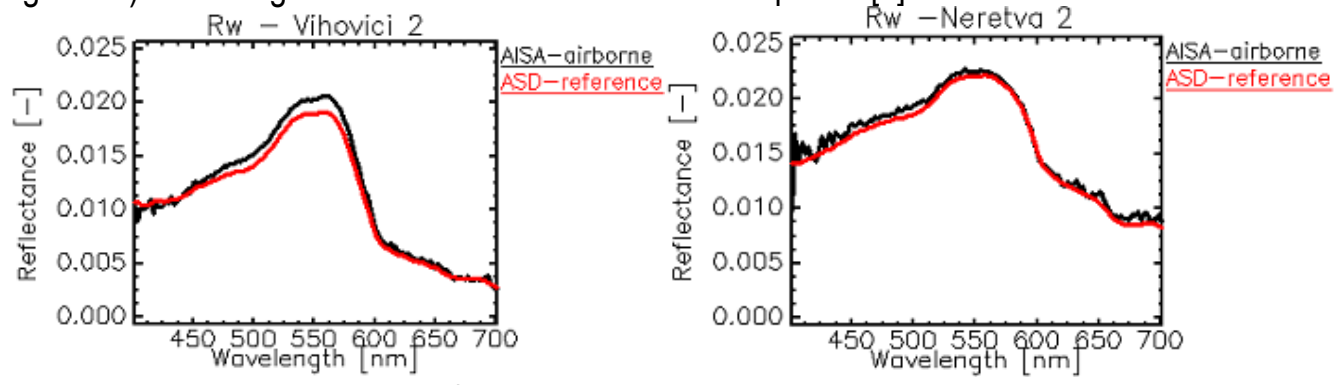

Figure 10 Validation of airborne Rw spectra with the in situ Rw spectra [7] 


\section{CONCLUSION}

To monitor the water quality of the Mostar Neretva River and Vihovici Lake, an extensive airborne and field campaign was organized, and a large amount of valuable data was collected. The airborne Rw spectra derived from the airborne data proved to be very similar to the in situ measurements of Rw spectra, and the linear regression could be inverted to generate water quality maps for each parameter under consideration. Linear regression analysis between the band ratios and the concentration measurements showed very strong relationships with nitrates $\left(R^{2}=0.82\right)$ and TSM $\left(R^{2}=0.72\right)$; strong relationship with CHL-a $\left(R^{2}=0.59\right)$; and weak relationship with cadmium $(R 2=0.19)$. The validation of the generated water quality maps showed good correlation and small RMSE for most of the parameters, but were influenced by bottom and adjacency effects.

The results and analyses presented in this paper lead to the conclusion that remote sensing data along with in situ measurements can be a useful tool for different environmental analyses.

\section{ACKNOWLEDGMENTS}

The authors would like to express their sincere gratitude to the team of experts from the Faculty of Civil Engineering University of Mostar that has participated in ImpactMin Project; thanks are due to M. Sc. Raić, in particular, for her patient guidance, keen interest and encouragement, and valuable and constructive suggestions.

\section{References}

[1] Tote, C.; Reusen, I. et al. 2010: Satellite mission planning for the demo sites, WP4 - Satellite remote sensing; Deliverable D4.3 December, 2010; pp. 14-36, http://www.impactmin.eu/downloads/impactmin_d43.pdf (Accessed 18.3.2015.)

[2] Ritchie, J.C.; Zimba, P.V.; Everitt, J.H. 2003: Remote sensing techniques to assess water quality, Photogrammetric Engineering \& Remote Sensing, 6, pp. 695-704, http://dx.doi.org/10.14358/PERS.69.6.695

[3] Delalieux, S.; Livens, S.; Goossens, M.; Reusen, I.; Tote, C. 2012: Spatial unmixing for environmental impact monitoring of mining using UAS and WV-2, Geophysical Research Abstracts, 14

[4] Bermana, E.S.F; Fladeland, M.; Liem, J.; Kolyer, R.; Gupta, M. 2012: Greenhouse gas analyzer for measurements of carbon dioxide, methane, and water vapor aboard an unmanned aerial vehicle, Sensors and Actuators B: Chemical, 169, pp. 128-135, http://dx.doi.org/10.1016/i.snb.2012.04.036

[5] Dörnhöfer, K.; Oppelt, N. 2016; Remote sensing for lake research and monitoring - Recent advances, Ecological Indicators, 64, pp. 105-122, http://dx.doi.org/10.1016/j.ecolind.2015.12.009

[6] Adey, E.A.; Shail, R.K.; et al.: Corporate social responsibility within the mining industry: case studies from across Europe and Russia, pp.156, (https://pure.Itu.se/portal/files/35955868/14_Uni_Exeter_Adey.pdf) (Accessed 2.4.2015.)

[7] Andricevic, R.; Kisevic, M.; et al.: Report on the Mostar, Case Study Investigations; WP7 - Demo-Site Implementation Deliverable D.7.2 pp. 3-112, (http://www.impactmin.eu/downloads/impactmin_d72.pdf ) (Accessed 9.4.2016.)

[8] Kruse, F.A.; Boardman J.W.; et al. 2003: Comparison of Airborne Hyperspectral Data and EO-1 Hyperion for Mineral Mapping; IEEE Transactions on Geoscience and Remote Sensing, 41(6), pp. 1338

[9] Smailbegović, A.; Delalileux, S.; et al. 2010: Airborne mission planning for demo sites, WP5 - Lightweight aerial remote sensing, Deliverable D5., pp. 5-26, (http://www.impactmin.eu/downloads/impactmin_d53.pdf) (Accessed 17.3.2015.) 